Witold Chmielewski

DOI: $10.14746 /$ BHW.2016.34.4

Instytut Nauk o Wychowaniu

Wydziat Pedagogiczny,

Akademia Ignatianum w Krakowie

\title{
Wyższe Studium Polskie przy Bibliotece Polskiej w Paryżu w 1945 roku
}

\begin{abstract}
The Polish College as part of the Polish Library in Paris in 1945
Following the German occupation of the French capital city, an idea sprang up in the Polish intellectual circles to intensify propagation of Polish culture and knowledge of Poland among young Polish and French people. This concept was to be implemented in the Polish Library in Paris by a series of lectures organized by the Department of Science of the Polish YMCA1 in France in late 1944. The success of the lectures encouraged the Polish Library to launch the Polish College with the goal of making available to primarily Polish youth, studying and working in Paris, the achievements of Polish science and culture and to prepare the young people for work in Poland. The curriculum was developed and, as expected, the College's operations were financed by the YMCA. Wacław Grzybowski, Ph.D., a former ambassador of Poland to the USSR, was appointed director of the College. The lecturers included illustrious intellectuals: priest Augustyn Jakubisiak, Ph.D., Franciszek Pułaski, Zygmunt Dygat, Irena Gałęzowska, Wieńczysław d’Ercville and many other. The College enjoyed considerable popularity among the students. The changing political situation in Poland put a stop to the promising operations of the College. To some extent, it was continued in the Catholic University of Paris ( the Institut Catholique de Paris). Since 1945, the University hosted the Centre for Slavic Studies where the Polish Section (Section Polonaise) was established.

It is worth emphasising that an ambitious attempt at establishing studies for young Poles abroad was made in Madrid, on the initiative of the Polish ambassador, count Józef Potocki, representing in Spain the Polish government in London.
\end{abstract}

Keywords: Polish College, Polish Library in Paris in 1945

Biblioteka Polska w Paryżu przy Quai d'Orléans 6 w okresie II wojny światowej początkowo stanowiła ważny element życia narodowego na uchodźstwie. Służyła pomocą powstałemu we Francji rządowi pod kierownictwem gen. Władysława Sikorskiego,

\footnotetext{
1 Young Men's Christian Association.
} 
wspierała swym księgozbiorem i zbiorami muzealnymi działalność utworzonego w Paryżu 1 grudnia 1939 r. polskiego Uniwersytetu za Granicą, kontynuowała prowadzone w okresie międzywojennym bogate i zróżnicowane formy pracy o charakterze kulturalnym, popularnonaukowym oraz naukowym ${ }^{2}$. Ten pomyślny rozwój działalności szacownej instytucji został przerwany przez kilkuletnią okupację niemiecką stolicy Francji. Placówka została zamknięta. Część najcenniejszych zbiorów została ewakuowana i ukryta W różnych częściach Francji. W dniu 28 października 1940 r. okupanci wywieźli do Niemiec 766 skrzyń książek i wartościowych eksponatów. Budynek Biblioteki ulegał dewastacji i niszczeniu z powodu nieopalania i złej eksploatacji ${ }^{3}$.

Dopiero wyzwolenie Paryża spod niemieckiego panowania zahamowało postępujący upadek narodowej instytucji. Do jej uruchomienia zgłosili się wszyscy żyjący przedwojenni pracownicy. Mimo braku środków finansowych i ogólnych, powojennych trudności postanowiono wznowić wszystkie obszary działalności placówki, a zwłaszcza biblioteczną, wystawienniczą i popularnonaukową, określaną jako wykładową. Ofiarność i oddanie zatrudnionych osób pozwoliły przezwyciężyć występujące problemy. Już 29 listopada 1944 r. zorganizowano pierwsze po zakończeniu okupacji niemieckiej zebranie publiczne, na którym dyrektor Biblioteki Polskiej poinformował zgromadzonych współpracowników i sympatyków instytucji o wojennych losach i aktualnych zadaniach stojących przed placówką. Wśród zebranych była wnuczka wielkiego poety, sędziwa Maria Mickiewiczówna i przedstawiciele francuskiego świata kultury ${ }^{4}$.

Reaktywowana działalność nie tylko nawiązywała do dotychczasowych form pracy, lecz starała się podejmować nowe inicjatywy. Jedną z nich, zasługującą na szczególną uwagę, było zorganizowanie przez Dział Naukowy Polskiej YMCA ${ }^{5}$ we Francji wspólnie z Biblioteką i w jej pomieszczeniach od 2 grudnia 1944 r. do 2 czerwca 1945 r. cyklu sobotnich odczytów, obejmujących zagadnienia z zakresu nauk historycznych, geograficznych, politycznych, literackich i prawniczych. Akcja ta wzorowana była na powszechnych wykładach uniwersyteckich, prowadzonych przez kilkadziesiąt lat przez Uniwersytet Jagielloński w Krakowie. Kierował nią bezpośrednio dr Marek Korowicz, kierownik Działu Naukowego. W omawianym okresie przeprowadzono w Bibliotece Polskiej 7 odczytów na tematy historyczne (ze szczególnym uwzględnieniem relacji polsko-francuskich). Wygłosili je: prof. Henri de Montfort - La politique polonaise de la France de 1793 à 1830, dr Marek Korowicz - Wielka Emigracja - fragment stosunków polsko-francuskich, dr Witold Kozłowski - Ziemia i człowiek, dr Olgierd Zdrojewski - Polskie pamiatki w Paryżu, dr Witold Kozłowski - W gdańskim zwierciadle, dr Zofia Korwin-Piotrowska - Polacy i Rewolucja Francuska, Tadeusz Leszczyc - Grabianka, Allan Kosko - Kraj w roku 1944. Tyleż samo zrealizowanych prelekcji dotyczyło problemów teryto-

2 W. Chmielewski, Przygotowanie kadr oświatowych na uchodźstwie. Seria: Monografie z Dziejów Oświaty, t. XVIII, Polska Akademia Nauk, Warszawa 2013, s. 19, 20.

3 F. Pułaski, Biblioteka Polska w Paryżu w latach 1893-1948. Odbito na prawach rękopisu w 350 egzemplarzach, Paryż 1948, s. 134-137.

4 Ibidem, s. 149.

5 Young Men's Christian Association (Chrześcijańskie Stowarzyszenie Młodzieży Męskiej). 
rialnych Polski, ze szczególnym uwzględnieniem Śląska i Prus Wschodnich: Józef Zieliński - Prusy Wschodnie, Jerzy Jankowski - Opis Prus Wschodnich, Jerzy Jankowski - Mazury $i$ Warmia - Polacy w Prusach Wschodnich, dr Czesław Chowaniec - Problem terytorialny Polski w dziejach, Stanisław Kudlicki - Górny Ślask w polskich celach wojny, dr Marek Korowicz - Górny Śląsk - ziemia i ludzie, tenże - Problemy Górnego Śląska. Pięć odczytów podejmowało zagadnienia gospodarcze i emigracyjne Polski. Referentami byli: prof. Bolesław Przegaliński - Polacy w świecie, Władysław Nowiński Emigracja polska w Ameryce Południowej i prof. Adam Rose, który wygłosił 3 wykłady na temat: Elementy równowagi w gospodarstwie polskim. Problematyka wojskowa została omówiona w trzech wystąpieniach: Romans Fajans - Polacy na Środkowym Wschodzie $i$ we Włoszech, płk Maria Leśniakowa - Pomocnicza stużba wojskowa kobiet, dr Olgierd Zdrojewski - 150 lat wojska polskiego we Francji. Zagadnienia polityczne i prawne przedstawione zostały w trakcie 5 odczytów. Autorami ich byli: Henryk KorabKucharski - Podstuchy niemieckich zwierzeń, dr Marek Korowicz - Problem zabezpieczenia pokoju na świecie, dr Ludwik Frendl - Demokracja we wspótczesnych konstytucjach, mgr Karol Stadniczenko - Istota państwa współczesnego, mgr Norbert Fiałkiewicz - Przełomy $w$ życiu narodów ${ }^{6}$. Zorganizowano też 3 prelekcje poświęcone sztuce i literaturze pięknej: Irena Gałęzowska - Cyprian Kamil Norwid - poeta przyszłości, Franciszek Black - Technika w rzeźbie, dr Jan Brzękowski - Nowa poezja francuska?.

Od pierwszych miesięcy swego istnienia odczyty cieszyły się zainteresowaniem „oświeconych sfer” środowiska polskiego w Paryżu, a w szczególności inteligencji starej emigracji. Było to uzależnione zwłaszcza od zakresu i popularności referowanego zagadnienia. Frekwencja na wykładach wahała się od 30 do 120 osób. Oceniano, że była wysoka i wskazywała, że istnieje społeczne zapotrzebowanie na tego typu edukację

$\mathrm{W}$ tej sytuacji pojawiła się inicjatywa, aby równolegle z prowadzoną akcją odczytową uruchomić zorganizowaną formę pewnego rodzaju studiów wyższych z wiedzy o Polsce dla dość licznej grupy polskiej młodzieży studiującej w Paryżu. Wystąpił z nią prezes Polskiej YMCA we Francji Zdzisław Woydat, deklarując zarazem przeznaczenie na realizację tego zadania znacznych środków finansowych. Zebranie w tej sprawie w gronie: Zdzisław Woydat, Marek Korowicz, Franciszek Pułaski - delegat Polskiej Akademii Umiejętności w Krakowie Ministerstwa Spraw Zagranicznych, a zarazem Dyrektor Biblioteki Polskiej w Paryżu i dr Wacław Grzybowski - były ambasador RP w Moskwie odbyło się w Bibliotece Polskiej w dniu 22 stycznia 1945 r. W trakcie spotkania Franciszek Pułaski poinformował uczestników narady, że podobna myśl, która ich tu zgroma-

${ }^{6}$ Towarzystw Historyczno-Literackie i Biblioteka Polska w Paryżu (dalej: THL i BPP), zespół: Archiwum Towarzystwa Historyczno-Literackiego i Biblioteki Polskiej w Paryżu (dalej: ATHL i BPP), akcesja (dalej: akc.) 6484, Odczyty Polskiej Y.M.C.A. w Bibliotece Polskiej w Paryżu w czasie od 2 grudnia 1944 r. do 2 czerwca 1945 r.; ibidem, Odczyty polskiej Y.M.C.K. we Francji. Grudzień 1944.

7 THL i BPP, ATHL i BPP, akc. 6484, Odczyty Polskiej Y.M.C.A. w Bibliotece Polskiej w Paryżu w czasie od 2 grudnia 1944 r. do końca kwietnia 1945 r. (wersja robocza); ibidem, Odczyty polskiej Y.M.C.A. we Francji. Grudzień 1944; ibidem, Zaproszenie polskiej YMCA na odczyty w dniu 9, 10, 13, 17 i 24 marca 1945 r.

8 THL i BPP, ATHL i BPP, akc. 6484, Odczyty Polskiej Y.M.C.A. w Bibliotece Polskiej w Paryżu w czasie od 2 grudnia 1944 r. do końca kwietnia 1945 r. (wersja robocza). 
dziła była już wdrażana w życie kilka lat przed wojną. Wychodząc bowiem na przeciw zapotrzebowaniu diaspory polskiej w Paryżu, a przede wszystkim młodych Francuzów wyrażających zainteresowanie historią, kulturą nauką i gospodarką naszego kraju, w dniu 16 lutego 1935 r. otwarto przy Bibliotece na Wyspie św. Ludwika Centrum Studiów Polskich (Centre d'Etudes Polonaises). Dyrekcję Centrum stanowili: Franciszek Pułaski - delegat PAU i MSZ, Zygmunt Lubicz Zaleski - delegat Ministerstwa Wyznań Religijnych i Oświecenia Publicznego i André Mazon - delegat francuskiego ministra Education Nationale. Dorobek instytucji był duży i zaowocował nie tylko edukacją młodzieży, ale także publikacjami Francuzów, często polskiego pochodzenia, na temat naszego kraju ${ }^{9}$.

Franciszek Pułaski uważał, że nowo organizowane studium powinno czerpać w swojej przyszłej działalności z bogatych doświadczeń Centrum Studiów Polskich, a w praktyce zostać złączone z jego strukturą organizacyjną. Występowałoby ono pod nazwą Polskich Wykładów Uniwersyteckich. Zaproponował uchwalenie tymczasowego statutu Wykładów. Sugerował, aby w dokumencie tym uzasadnić potrzebę powołania takiej instytucji edukacyjnej i określić jej zadanie, które miało na celu głównie kształcenie młodzieży polskiej przebywającej w Paryżu $w$ zakresie języka, literatury, historii kultury $i$ w ogóle kultury polskiej ${ }^{10}$. Władze Centrum Studiów Polskich miały m.in. czuwać nad składem grona wykładowców, programem zajęć, dbać o autonomiczność organizacji Wykładów. Pułaski wysunął propozycję druku najbardziej interesujących rozpraw powstałych w przyszłości w nowo tworzonej instytucji. Ze strony przedstawicieli YMCA pojawiły się sugestie nawiązania do tradycji działalności Uniwersytetu Polskiego za Granicą, który istniał w Paryżu pod koniec 1939 r. i w 1 poł. 1940 r. Uczestnicy zebrania określili szczegółowy tok prac na najbliższe dni nad organizacją i programem tworzonych studiów ${ }^{11}$. Zapoznali się również z przygotowanym programem studiów, który przewidywał 114 godzin zajęć, obejmujących zagadnienia $\mathrm{z}$ historii łącznie $\mathrm{z}$ historią literatury polskiej, nauk prawnych i zagadnień geograficznych wraz problematyką gospodarczą. Na wykładowców proponowano m.in.: Władysława Pobóg-Malinowskiego, ks. dr. Augustyna Jakubisiaka, dr. Wacława Grzybowskiego. Zajęcia miały być realizowane w poniedziałki, środy i piątki w godzinach od 17.00 do $19.00^{12}$.

Wdrażanie w życie ustaleń z 22 stycznia przybrało dużą intensywność. Wkrótce opracowano ważny dokument o charakterze prawnoorganizacyjnym, który zawierał stwierdzenia dotyczące wdrażanej w życie formy cyklu wykładów, formułował jej oficjalne źródło powstania, a przede wszystkim nową, niewymienianą wcześniej, nazwę. Dokument ten określono mianem Regulaminu Wyższego Studium Polskiego przy Bibliotece Polskiej w Paryżu. W pierwszych jego zdaniach zapisano: 1. Na mocy porozumienia

\footnotetext{
9 Ibidem, Pismo Z. Woydata z 18 stycznia 1945r. do F. Pułaskiego; Notatka F[ranciszka ] P[ułaskiego] odczytana 22 I [19]45 na posiedzeniu Y.M.C.[A]w B[ibliote]ce Polskiej.

${ }^{10}$ Ibidem, F. Pułaski, Polskie wykłady uniwersyteckie przy Centre d'Etudes Polonaises w pierwszym pótroczu 1945(od 15II do 15VII [19]45).

${ }^{11}$ Ibidem.

12 Ibidem, Projekt programu nauk.
} 
Delegata Ministerstwa Wyznań Religijnych i Oświecenia Publicznego z Delegatem Polskiej Akademii Umiejętności, jako Dyrektorem Biblioteki Polskiej w Paryżu oraz z Prezesem Polskiej Y.M.C.A we Francji zostanie powołane do życia w czasie obecnej wojny Wyższe Studium Polskie. 2. Celem Studium jest umożliwienie przede wszystkim młodzieży polskiej, studiujacej i pracujacej w Paryżu, zapoznanie się z zagadnieniami nauki i kultury polskiej i przygotowanie jej w ten sposób do pracy w Polsce ${ }^{13}$.

Zgodnie z wcześniejszą zapowiedzią finansowania działalności Studium podjęła się YMCA. Wykłady postanowiono prowadzić w Bibliotece Polskiej. Kierownictwo Studium powierzono Radzie, w której skład wchodzili: delegat Ministerstwa WRiOP we Francji, delegat PAU, przewodniczący Komitetu Polskiego YMCA we Francji - Wacław Grzybowski i prezes polskiej YMCA w tym kraju. Rada wybrała ze swojego grona prezesa, który został jednocześnie dyrektorem Studium. Był nim W. Grzybowski. Sekretarzem Rady i sekretarzem Studium został Marek Korowicz. Do kompetencji Rady Studium należało opracowanie ,programu nauk”, który był przyjmowany jednomyślną uchwałą tego organu. Rada zatwierdzała również budżet Studium i zapraszała wykładowców do prowadzenia zajęć. W zależności od potrzeb i swojego uznania przewodniczący Rady zwoływał co pewien czas zebranie Grona Wykładającego. Do jego zadań należało omawianie spraw techniczno-organizacyjnych, związanych z prowadzeniem wykładów, ocena pracy słuchaczy i osiąganych wyników w nauce oraz kwestie dotyczące egzaminów. Studia były bezpłatne. Słuchacze dzielili sie na zwyczajnych i wolnych. Słuchaczami zwyczajnymi były te osoby, które słuchały wykładów, brały udział w co najmniej jednym konwersatorium, poddawały się ocenie Grona Wykładającego i otrzymywały świadectwo ukończenia kursu. Słuchacze wolni uczęszczali na wybrane cykle wykładów i nie ubiegali się o uzyskanie świadectwa. Kryteria oceny słuchaczy zatwierdzała Rada na wniosek Grona Wykładającego. Ocenie słuchaczy przewodniczył delegat Ministerstwa WRiOP ${ }^{14}$.

Uroczyste otwarcie Wyższego Studium Polskiego odbyło się w obecności ambasadora RP we Francji Kajetana Morawskiego w dniu 21 lutego 1945 r. w budynku Biblioteki Polskiej w Paryżu ${ }^{15}$. W trakcie uroczystości z programowym przemówieniem wystąpił dyrektor Studium dr Wacław Grzybowski. Stwierdził on, że kierowana przez niego instytucja nie nawiązuje do istniejącego w 1939 r. i 1940 r. Uniwersytetu Polskiego za Granicą, lecz stanowi wyraz Polski walczacej nie tylko o swoją niepodległość państwowa, ale

\footnotetext{
${ }_{13}$ Archiwum Instytutu Polskiego i Muzeum im. gen. Władysława Sikorskiego w Londynie (dalej: IPMS), zespół: Ministerstwo Wyznań Religijnych i Oświecenia Publicznego (dalej: MWRiOP), sygn. A. 19.II/14, Regulamin Wyższego Studium Polskiego przy Bibliotece Polskiej w Paryżu. Delegatem Ministerstwa WRiOP rządu polskiego w Londynie na terenie Francji był ks. dr Augustyn Jakubisiak. Takim samym delegatem był powołany wcześniej na tę funkcję Zygmunt Lubicz-Zaleski, który w tym czasie był przetrzymywany przez Niemców Buchenwaldzie. Należy też zaznaczyć, że istniała w Paryżu na Batignolles w latach 1855-1862 placówka edukacyjna o zbliżonej nazwie - Wyższa Szkoła Polska, por.: H. Natuniewicz, Zbiory i prace polonijne Muzeum Literatury im. Adama Mickiewicza $w$ Warszawie, Biblioteka Narodowa, Muzeum Literatury im. A. Mickiewicza, Warszawa 1984, s. 47.

${ }^{14}$ IPMS, MWRiOP, sygn. A. 19.II/14, Regulamin Wyższego Studium Polskiego przy Bibliotece Polskiej w Paryżu.

15 Ibidem, Pismo radcy Ambasady RP w Paryżu z 8 marca 1945 r. do ministra WRiOP.
} 
także o niezależność, trwanie i rozwój polskiej myśli naukowej. Gdzie tylko okoliczności pozwalaja, pomnażanie i pogtębianie wiedzy o Polsce jest nieodzownym ogniwem tej walki. Podkreślił, że pierwszym celem Studium jest ułatwienie stuchaczom zdobycia potrzebnych im wiadomości o sprawach i zagadnieniach polskich. Drugim - jest wprowadzenie ich $w$ obręb polskich metod badania i formułowania, w atmosfere polskiej twórczości, w klimat polskiej myśli, co jest nieodzownym warunkiem dla poznania i zrozumienia polskiej rzeczywistości, polskich dotychczasowych osiagnięć, polskich instytucji $i \operatorname{praw}^{16}$.

Następnie scharakteryzował tok zajęć i kadrę wykładowców. Podkreślił, że składa się ona jakby z dwóch grup. Do pierwszej zaliczają się uczeni i pracownicy z dużym dorobkiem naukowym. Do drugiej - osoby z dużym doświadczeniem na polu praktycznego działania. Kilkoro wykładowców wyróżniło się ratowaniem skarbów kultury narodowej w czasie wojny lub bezpośrednim udziałem w walce o niepodległość lub działalnością w konspiracji. Zauważył, że rdzennie polska myśl ukształtowana na przestrzeni wieków uznaje prymat ducha nad rzeczywistością materialną, odznacza się głębokim humanizmem i dużym ładunkiem moralnym. Wykłady na otwieranym Studium mają na celu ukazanie i naświetlenie tych problemów oraz umocnienie polskości wśród słuchaczy, mają uczynić go miejscem walki o niezależność Polski. Realizacji tych zadań będzie służyć atmosfera Stacji Naukowej Polskiej Akademii Umiejętności i jej bogaty księgozbiór, sprzyjający rozwijaniu zainteresowań naukowych i badawczych uczestników Studium ${ }^{17}$.

Z kolei do zebranych przemówił delegat Ministerstwa WRiOP we Francji ks. dr Augustyn Jakubisiak, który odwołując się do zasadniczych myśli swojego systemu filozoficznego stwierdził, że wykładowcy Studium będą na konwersatoriach oczekiwać od przyszłych słuchaczy nie biernej postawy, sceptycyzmu, uzależnionego od zewnętrznych okoliczności, ale opowiadają się za zachowaniami aktywnymi, przemyślanymi, wynikającymi z dojrzałego osobistego wyboru ${ }^{18}$. Wykład inauguracyjny pt. Karol Sienkiewicz i Władysław Mickiewicz założyciele Biblioteki Polskiej i Muzeum Adama Mickiewicza wygłosił dyrektor Biblioteki Polskiej w Paryżu - Franciszek Pułaski. We wstępie swojego wystąpienia nawiązał on do idei emigracji, towarzyszącej królowi Stanisławowi Leszczyńskiemu, związanej ze zorganizowaną dobroczynnością społeczną. Wskazał na znaczenie haseł wolnościowych i demokratycznych emigracji Konfederatów Barskich, wędrówkę żołnierzy napoleońskich i emigrację po powstaniu listopadowym, która szczególnie wyraźnie zaznaczyła swoją obecność na ziemi francuskiej. Po tych uwagach wprowadzających mówca skoncentrował rozważania na obszernym przedstawieniu działalności i zasług Karola Sienkiewicza w założeniu Biblioteki i Władysława Mickiewicza w utworzeniu Muzeum Adama Mickiewicza. Wykład Pułaskiego znacznie przybliżył ze-

${ }^{16}$ THL i BPP, ATHL i BPP, akc. 6484, Przemówienie wstępne Prezesa Rady Wyższego Studium Polskiego przy Bibliotece Polskiej w Paryżu D[oktor]a W. Grzybowskiego.

17 Ibidem.

${ }^{18}$ Ibidem, Biblioteka Polska w Paryżu, Bibliothèque Polonaise de Paris. 
Tabela 1. Program i plan zajęć w Wyższym Studium Polskim w 1945 r.

\begin{tabular}{|c|c|c|c|}
\hline \multirow[b]{2}{*}{ Wykładowcy } & \multirow[b]{2}{*}{ Temat } & \multicolumn{2}{|c|}{ Liczba godzin } \\
\hline & & wykłady & $\begin{array}{l}\text { konwersato- } \\
\text { rium }\end{array}$ \\
\hline \multicolumn{4}{|c|}{ I. Dział Humanistyczny } \\
\hline Ks. dr Augustyn Jakubisiak & Problem nowego człowieka & 10 & 2 \\
\hline Dr Wacław Grzybowski & $\begin{array}{l}\text { Z dziejów polskiej kultury: Polska myśl } \\
\text { polityczna }\end{array}$ & 10 & 3 \\
\hline Franciszek Pułaski & Z dziejów kultury emigracji & 4 & 1 \\
\hline Irena Gałęzowska & $\begin{array}{l}\text { Psychologia i socjologia w literaturze } \\
\text { polskiej }\end{array}$ & 8 & 2 \\
\hline Dr Czesław Chowaniec & Problem mórz i granic Polski & 8 & 2 \\
\hline Wieńczysław d’Erceville & Uwagi o malarstwie polskim & 4 & 1 \\
\hline Zygmunt Dygat & $\begin{array}{l}\text { Muzyka polska(klasyczna, romantyczna } \\
\text { i współczesna) }\end{array}$ & 4 & - \\
\hline Razem & & 48 & 11 \\
\hline \multicolumn{4}{|c|}{ II. Dział Prawny } \\
\hline Dr Marek Korowicz & Polska doktryna prawa międzynarodowego & 10 & 2 \\
\hline Mgr Leszek Karpiński & Zasady polskiego prawa konstytucyjnego & 5 & 1 \\
\hline Mec. Stefan Jankowski & $\begin{array}{l}\text { Ustrój administracji i sądownictwa oraz } \\
\text { zasady polskiego prawa administracyjnego }\end{array}$ & 4 & 1 \\
\hline Mec. Stefan Jankowski & $\begin{array}{l}\text { Zasady polskiego prawodawstwa } \\
\text { społecznego }\end{array}$ & 4 & 1 \\
\hline Dr Ludwik Frendl & $\begin{array}{l}\text { Zasady polskiego prawa cywilnego } \\
\text { i handlowego }\end{array}$ & 8 & 2 \\
\hline SSN Walfisz & Zasady polskiego praw karnego & 4 & 1 \\
\hline Razem & & 35 & 8 \\
\hline \multicolumn{4}{|c|}{ III. Dział Ekonomiczno-Społeczny } \\
\hline Zdzisław Woydat & Problemy agrarne w Polsce & 6 & 2 \\
\hline $\begin{array}{l}\text { Bolesław Przegaliński, } \\
\text { Stanisław Gryziewicz }\end{array}$ & $\begin{array}{l}\text { Spółdzielczość polska (polski socjalizm } \\
\text { zrzeszeniowy) }\end{array}$ & 6 & 2 \\
\hline Ogółem & & & \\
\hline
\end{tabular}

Źródło: THL i BPP, ATHL i BPP, akc. 6484, Program nauk Wyższego Studium Polskiego w Paryżu. 
branym narodowe znaczenie Biblioteki w okresie ważnych wydarzeń zachodzących w Europie i w Polsce ${ }^{19}$.

Tematykę zajęć Wyższego Studium Polskiego podano do wiadomości publicznej na specjalnie wydanym plakacie z zaznaczeniem, że przewiduje się jego dalsze uzupełnie$n^{20}$. Obejmował on trzy działy: humanistyczny, prawny i ekonomiczno-społeczny. Zajęcia odbywały się w poniedziałki, środy i piątki w godzinach wieczornych. $\mathrm{W}$ ciągu tygodnia realizowano 6 godzin wykładów i 4 godziny konwersatorium ${ }^{21}$.

Realizacja nakreślonego planu napotykała obiektywne trudności. Nie wszystkie zajęcia udało się zrealizować. Zdzisław Woydat nie zdołał wygłosić wszystkich 6 godzin wykładów poświęconych problemom agrarnym w Polsce, ponieważ musiał wywiązać się z ważnych obowiązków służbowych i przez dłuższy czas przebywał w Wielkiej Brytanii. Zaledwie jeden wykład przeprowadził ks. dr Augustyn Jakubisiak. Z pozostałych zajęć na Studium musiał zrezygnować z powodu wypełniania rozlicznych zadań wynikających ze stanowiska delegata Ministerstwa WRiOP. Z kolei Czesław Chowaniec nie zrealizował jednego wykładu i dwóch konwersatoriów ze względu na nadmiar obowiązków służbowych. Marek Korowicz powiększył natomiast cykl swoich zajęć na temat polskiej doktryny prawa międzynarodowego o dwie godziny. Studium zakończyło zajęcia w dniu 6 lipca 1945 r. ${ }^{22}$

Ogólna liczba słuchaczy zwyczajnych i wolnych wynosiła 78 osób. Przeważały osoby starsze. Mniej niż się spodziewano, uczęszczało na zajęcia studentów. Fakt ten tłumaczono uruchomieniem Studium w połowie roku akademickiego, gdy młodzież miała już wypełniony czas. Frekwencja była zróżnicowana i wynosiła od 8 do 70 osób. Na niektóre przybywała dość duża liczba osób w ogóle niezapisanych. Dyrekcja Studium otrzymała wiele podziękowań od słuchaczy za interesujący dobór zajęć. Ośmioro uczestników kursu odznaczyło się wyjątkową pilnością. Pięcioro spośród nich otrzymało z tego tytułu nagrody w wysokości po 2 tys. franków. Byli to: Janina Antosz, Bronisław Czerwiński, Helena Gacka, Alfred Nowak i Marta Osuchowska ${ }^{23}$.

Pozytywne wyniki pracy Wyższego Studium Polskiego skłoniły Zdzisława Woydata do wystąpienia w imieniu polskiej YMCA we Francji z inicjatywą uruchomienia kolejnego cyklu zajęć w budynku Biblioteki Polskiej od 1 listopada 1945 r. do 1 lipca 1946 r. W tym celu przedłożył on Franciszkowi Pułaskiemu program studiów i zwrócił się z prośbą o wynajęcie pomieszczeń w budynku Biblioteki na prowadzenie zajęć. Propozycja została przyjęta. Pułaski zasugerował, aby nadesłany program został zatwierdzony przez Ministerstwo WRiOP w Londynie i odpowiadał wymaganiom stawianym przez

\footnotetext{
${ }_{19}$ Ibidem; IPMS, MWRiOP, sygn. A. 19.II/14, Zaproszenie na uroczystość otwarcia Wyższego Studium Polskiego przy Bibliotece Polskiej w Paryżu w środę 21 lutego 1945 r.

${ }^{20}$ IPMS, MWRiOP, sygn. A. 19.II/14, Plakat o uruchomieniu Wyższego Studium Polskiego przy Bibliotece Polskiej w Paryżu.

${ }^{21}$ Ibidem, Pismo radcy Ambasady RP w Paryżu z 8 marca 1945r. do ministra WRiOP.

${ }_{22}$ THL i BPP, ATHL i BPP, akc. 6484, Notatka sprawozdawcza z prac Wyższego Studium Polskiego przy Bibliotece Polskiej w Paryżu.

${ }^{23}$ Ibidem.
} 
Tabela 2. Program i plan zajęć Kursu Nauk Politycznych Wyższego Studium Polskiego. Rok akademicki1945/1946

\begin{tabular}{|c|c|c|c|}
\hline \multirow{2}{*}{ Przedmiot } & \multirow{2}{*}{ Wykładowca } & \multicolumn{2}{|c|}{ Liczba } \\
\hline & & wykładów & seminariów \\
\hline $\begin{array}{l}\text { Historia politycznego i społecznego ustroju } \\
\text { polski na tle porównawczym }\end{array}$ & Michał Szczaniecki & 45 & 9 \\
\hline $\begin{array}{l}\text { Współczesne ustroje polityczne i administracyj- } \\
\text { ne. Podstawowe problemy administracji w } \\
\text { Polsce }\end{array}$ & Jerzy Langrod & 45 & 9 \\
\hline $\begin{array}{l}\text { Zagadnienia polskiej polityki gospodarczej na } \\
\text { tle współczesnej gospodarki światowej }\end{array}$ & Adam Rose & 45 & 9 \\
\hline $\begin{array}{l}\text { Główne problemy prawa międzynarodowego } \\
\text { publicznego oraz zasady prawa dyplomatyczne- } \\
\text { go, konsularnego i morskiego }\end{array}$ & Marek Korowicz & 45 & 9 \\
\hline Technika handlu zagranicznego & Alfred Siebeneichen & 15 & 2 \\
\hline $\begin{array}{l}\text { Spółdzielczość w gospodarstwie polskim i } \\
\text { światowym }\end{array}$ & Bolesław Przegaliński & 10 & 2 \\
\hline Odzyskane Ziemie Zachodnie & $\begin{array}{l}\text { Roman Lutman } \\
\text { (Śląsk) }\end{array}$ & 20 & 4 \\
\hline $\begin{array}{l}\text { Zarys geografii politycznej i gospodarczej } \\
\text { Europy i posiadłości francuskich ( bez ZSSR i } \\
\text { Wielkiej Brytanii) }\end{array}$ & Bolesław Przegaliński & 20 & 4 \\
\hline $\begin{array}{l}\text { Zarys geografii politycznej i gospodarczej } \\
\text { Imperium Brytyjskiego, Stanów Zjednoczonych } \\
\text { Ameryki Północnej i Ameryki Łacińskiej }\end{array}$ & Stanisław Sembrat & 20 & 4 \\
\hline $\begin{array}{l}\text { Geografia polityczna i gospodarcza ZSSR } \\
\text { Bliskiego i Dalekiego Wschodu }\end{array}$ & Alfred Siebeneichen & 20 & 4 \\
\hline Polska w kulturze świata & $\begin{array}{l}\text { Zygmunt } \\
\text { Lubicz-Zaleski }\end{array}$ & 20 & 4 \\
\hline Francja i Polska & $\begin{array}{l}\text { Zygmunt } \\
\text { Lubicz-Zaleski }\end{array}$ & 10 & 2 \\
\hline Razem & & 310 & 62 \\
\hline
\end{tabular}

Ź r ó d ł o: THL i BPP, ATHL i BPP, akc. 6484, Wyższe Studium Polskie Polskiej YMCA we Francji. Rok szkolny 1945/46. Kurs Nauk Politycznych. 
władze francuskie. Prosił także, aby YMCA uczestniczyła w pokrywaniu kosztów opału, oświetlenia budynku i wyposażenia sal wykładowych ${ }^{24}$. Planowano, że wpisy na Wyższe Studium Polskie odbędą się w dniach 10 - 30 października 1945 r. Tematyka zajęć proponowanych przez YMCA miała koncentrować się wokół zagadnień politycznych.

Ambitny plan kontynuowania zajęć w ramach Wyższego Studium Polskiego przy Bibliotece Polskiej nie został wprowadzony w życie. Jak bowiem wcześniej wspomniano Studium działało w ramach istniejącego przed wojną Centrum Studiów Polskich. W skład dyrekcji Centrum na podstawie statutu wchodzili ministrowie właściwi dla spraw oświaty z Francji i Polski. Po uznaniu przez Francję Tymczasowego Rządu Jedności Narodowej członkiem dyrekcji zostałby więc minister rządu warszawskiego. Franciszek Pułaski obawiał się takiej sytuacji i przerwał wykłady realizowane w ramach Centrum. Dzięki dyrektorowi Biblioteki zajęcia prowadzone w ramach Centrum Studiów Polskich zostały przeniesione do Instytutu Katolickiego w Paryżu (Institut Catholique de Paris). W ramach tej placówki naukowej założono w 1945 r. Centrum Studiów Słowiańskich (Centre d'Etudes Slawes), w którym utworzono Sekcję Polską (Section Polonaise) ${ }^{25}$. Koncentrowała się w niej przez wiele lat najwyższa forma działalności edukacyjnej polskiego środowiska intelektualnego w Paryżu na temat problematyki dotyczącej naszego kraju, przeznaczonej dla studentów francuskich i polskich. Tylko w roku akademickim 1945/1946, realizując program uwzględniający niezależną polską rację stanu zajęcia prowadzili: Paul Cazin, prof. Zygmunt Lubicz-Zaleski, prof. A.M Chmurski, prof. Jan Żarnowski, prof. Henri de Montfort, Irena Gałęzowska. Z grona wykładowców śmierć wyrwała ks. Augustyna Jakubisiaka ${ }^{26}$. Idea edukacji polskiej młodzieży na emigracji i uchodźstwie była więc podtrzymywana i rozwijana.

W kręgu Polskiej YMCA, w łączności z osobami skupionymi wokół Biblioteki Polskiej, pojawiała się też kolejna ambitna i niełatwa w realizacji koncepcja zmierzająca do zorganizowania uczelni polskiej we Francji. Miała ona nosić nazwę Wyższego Studium Prawa i Nauk Politycznych w Paryżu. Przewidywano, że placówka ta, podlegająca nadzorowi państwowych władz szkolnych, będzie miała charakter prywatnej szkoły akademickiej z prawami publicznym. Jej zadaniem będzie umożliwienie młodzieży odbywanie studiów prawniczych, łącznie z dokończeniem rozpoczętych przed wojną w kraju, kształcenie młodych kadr naukowych, rozszerzenie współpracy intelektualnej Polski z zagra-

\footnotetext{
${ }^{24}$ Ibidem, Kopia pisma F. Pułaskiego z 7 sierpnia 1945 r. do Z. Woydata.

${ }^{25}$ Ibidem, Pismo F. Pułaskiego z 7 stycznia 1946 r. do A. Żółtowskiego; ibidem, Pismo Franciszka Pułaskiego z 10 listopada 1945 r. do P. Cazina. Pułaski m.in. pisze w nim: Teraz wchodzimy w nowy rok akademicki, który będzie rokiem ciężkiej dla nas próby. Ze zrozumiatych dla Pana powodów administracyjnej natury, nie chcac się poddawać wplywom $w$ administracji Centrum [Studiów Polskich] wplywom prowizorycznego rządu [Tymczasowego Rządu Jedności Narodowej w Warszawie - przyp. WCh], który miałby potem statutowe uprawnienia, z boleścia $w$ sercu zrezygnować musiatem z wykładów w Centrze, przynajmniej na pierwszy semestr tego roku. I tak do wczoraj rzeczy się przedstawiały. Ale rozmowa, jaka miałem wczoraj z Rektorem Instytutu Katolickiego Calvetem odmieniła smutny stan rzeczy. Rektor Calvet najchętniej się zgodził na zorganizowanie sekcji polskiej w założonym $w$ tym roku przy Instytucie Katolickim Centre d'Etudes Slawes [...], która by wypetnity w tym roku wykłady stanowiace dalszy ciąg naszych wykładów w naszym Centre d'Etudes Polonaises.

${ }^{26}$ Institut Catholique de Paris Centre d'Etudes Slawes Section Polonaise. Programme des Cours Libres année 1945-1946.
} 
nicą, a zwłaszcza z Francją. W Studium zamierzano realizować czteroletni kurs prawa według polskiego programu studiów oraz trzyletnią Szkołę Nauk Politycznych, przeznaczoną także dla studentów prawa. Szkoła Nauk Politycznych miała być przeznaczona dla szerszych kręgów polskiej społeczności w Paryżu i pełnić w pewnym sensie rolę Uniwersytetu Powszechnego. Zakładano również możliwość zorganizowania prelekcji na prowincji. Projektowano, że kierownictwo Wyższego Studium Prawa i Nauk Politycznych w Paryżu obejmie wybitny prawnik przebywający aktualnie we Francji, prof. Uniwersytetu Jagiellońskiego - Jerzy Langrod. Zamierzano zorganizować kilka stałych katedr i postawić na ich czele polskich prawników związanych obecnie z Oksfordem pod Londynem oraz wykorzystać miejscową kadrę (dr Wacław Grzybowski, Marek Korowicz). Przewidywano utworzenie Bursy Studenckiej przez Polską YMCA dla około 100 studentów i przyznawanie im stypendiów ze środków finansowych PCK. Realizacja tej koncepcji miała się odbywać poza budżetem Ministerstwa WRiOP. Studium powinno znaleźć lokalizację w Bibliotece Polskiej, Domu Polskim przy rue Crillon i w Hotelu Lambert. Zakładano, że celem sprawnej realizacji projektu decyzja o jego wdrożeniu w życie powinna zapaść najpóźniej przed 1 lipca 1945 r. Względy natury politycznej, finansowej i kadrowej spowodowały, że realizacja tej idei nie znajdowała odpowiednich warunków do wcielenia jej w życie ${ }^{27}$.

Interesująca koncepcja kształcenia młodzieży polskiej na poziomie wyższym pojawiła się w Madrycie. Urzędujący w tym mieście ambasador RP Józef Potocki, reprezentujący polski rząd w Londynie, po rozmowie z hiszpańskim ministrem spraw zagranicznych Alberto Martinem Artojo w liście do Franciszka Pułaskiego informował, że istnieje możliwość utworzenia na terenie Hiszpanii ośrodka uniwersyteckiego dla polskiej młodzieży studenckiej. Inicjatywa ta zdaniem ambasadora była ze wszech miar interesująca i zasługująca na uwagę. Przyniosłaby ona duże korzyści polskiej młodzieży na obczyźnie, zwłaszcza w Hiszpanii i przyczyniłaby się w widoczny sposób do zbliżenia polskohiszpańskiego na skalę, jakiej w historii stosunków między obydwoma państwami wcześniej nie notowano ${ }^{28}$.

Stanowisko ministra spraw zagranicznych w tej sprawie potwierdził, również po przeprowadzonej rozmowie, profesor Uniwersytetu w Sewilli Ruiz Gimenez, jeden z przywódców hiszpańskich działaczy katolickich. Wytypowano siedzibę dla przyszłego ośrodka uniwersyteckiego. Planowano przeznaczyć na nią nieużytkowane gmachy uniwersyteckie pod Madrytem Alcalá [de] Henares. Główny ciężar finansowy utrzymania placówki miały ponieść organizacje katolickie w Stanach Zjednoczonych Ameryki Północnej i organizacje hiszpańskie. Oficjalnie Ośrodek służyłby cudzoziemcom z całego kontynentu europejskiego. Faktycznie byłby przeznaczony przede wszystkim dla Polaków. Oceniano, że realizacja tej inicjatywy ma szczególne znaczenie w czasie, gdy następowało stopniowe przygotowanie do zakończenia działalności polskich wydziałów na uczelniach brytyjskich. Przewidywano, że w pierwszym etapie realizacji tego zadania $\dot{z} u[\ldots]$.

${ }^{27}$ THL i BPP, ATHL i BPP, akc. 6484, Projektowane Wyższe Studium Prawa i Nauk Politycznych w Pary${ }^{28}$ Ibidem, akc. 6484/3,Pismo J. Potockiego z 16 stycznia 1946 r. do F. Pułaskiego. 
liczba studentów powinna obejmować od 50 do 80 lub 100 osób. Rozważano też kwestię skompletowania listy wykładowców ${ }^{29}$.

W realizację szczytnego zadania zaangażował się Franciszek Pułaski, który pragnął służyć swoim doświadczeniem nabytym w czasie organizowania działalności Centrum Studiów Polskich przed wojną i kierowaniem różnymi formami pracy Biblioteki Polskiej $^{30}$. Pułaski opracował koncepcję kształcenia studentów polskich w Madrycie w placówce zwanej Collegium Polskim. Swoje przemyślenia na ten temat przesłał kierownikowi Ministerstwa WRiOP w Londynie, prof. Władysławowi Folkierskiemu i posłowi Józefowi Potockiemu. Dyrektor Biblioteki podkreślił, że dużym osiągnięciem polskiego posła w Madrycie jest uzyskanie od rządu hiszpańskiego zgody na utworzenie polskiego ośrodka uniwersyteckiego, a ponadto obsadzenie kilku katedr na Uniwersytecie Madryckim przez Polaków. Proponował, aby instytucję tę nazwać Collegium Polskim. Stwierdził, że ówczesna Hiszpania była bliska narodowi polskiemu pod względem ideowym i kulturowym, bardziej nawet niż Francja. Podkreślił, że przyjazne stanowisko władz tego kraju wobec idei zorganizowania polskich studiów na poziomie uniwersyteckim oraz perspektywa zatrudnienia pracowników nauki zasługuje na szczególną uwagę. Uznał, że fakt ten należy szczególnie docenić, ponieważ w innych krajach pojawiają sie trudności w kształceniu młodzieży na poziomie uniwersyteckich (najprawdopodobniej miał tu na myśli rysującą się coraz wyraźniej kwestię likwidacji polskich wydziałów na wyższych uczelniach Wielkiej Brytanii). Zauważył, że studia Polaków i działalność naukowa w języku hiszpańskim może przyczynić się do krzewienia polskości w Ameryce Łacińskiej i pozytywnie wpłynąć na wykorzystanie dorobku kulturalnego i naukowego Hiszpanii w rozwoju nauki polskiej. Dopuszczał także możliwość wywiezienia do tego kraju, w razie powstania zagrożenia, np. ze strony Związku Sowieckiego, skarbów kultury polskiej, znajdujacych się we Francji ${ }^{31}$.

Franciszek Pułaski postulował: Collegium Polskie w sławnem z czasów [Miguela de] Cervantesa Alcaláde [de] Henares pod Madrytem składałoby się: a) z ciała nauczajacego w zakresie nauk polonistycznych, a zatem: prawa, historji literatury, historji sztuki polskiej, przyczem jeden z wykładajacych, np. z historji kościoła czy filozofji byłby duchownym katolickim i spetniałby, czyniac zadość tradycjom hiszpańskim, role katechety tego Collegium, b) z grupy 50 do 100 starannie dobranych studentów, majacych się kształcić zawodowo w wyższych uczelniach hiszpańskich i uczęszczających obowiązująco na zorganizowanych dla nich wykładach wspomnianego wyżej ciała profesorskiego ${ }^{32}$.

Realizacją wdrożonej w życie koncepcji studiów miał kierować mianowany przez Ministerstwo WRiOP w Londynie dyrektor, przy wsparciu przedstawicieli (delegatów) władz oświatowych Polski i Hiszpanii, mianowanych na trzy lata oraz Rada Nadzorcza, złożona z wybitnych uczonych hiszpańskich. Franciszek Pułaski proponował, aby Colle-

\footnotetext{
${ }^{29}$ Ibidem, Pismo J. Potockiego z15 stycznia 1946 r. do F. Pułaskiego.

${ }^{30}$ Ibidem, Pismo F. Pułaskiego z 1lutego 1946r do J. Potockiego.

31 Ibidem, Notatka wstępna o Collegium Polskim w Madrycie, ułożona przez Fr[anciszka] Pułaskiego dla Pana Ministra Folkierskiego.

${ }^{32}$ Ibidem.
} 
gium Polskie kierowało się statutem wzorowanym na podobnym akcie Centrum Studiów Polskich Biblioteki Polskiej w Paryżu. Collegium miało wydawać periodyk (kwartalnik lub półrocznik), w którym byłyby zamieszczane sprawozdania oraz prace naukowe profesorów polskich i hiszpańskich, a także wyróżniających się studentów. Rekrutację studentów należało prowadzić starannie, głównie na terenie Włoch, Francji, Belgii i Niemiec. Młodzież akademicka powinna jak najwcześniej znaleźć się w Collegium, aby móc szybko opanować język hiszpański i słuchać głoszonych w nim wykładów na wyższych uczelniach madryckich. Pierwszy rok zajęć w Collegium Polskim odbywałby się w języku polskim, a w następnych latach również w języku hiszpańskim. Polscy profesorowie powinni opanować język hiszpański w ciągu półtora roku. Umożliwiłoby im to prowadzenie wykładów na Uniwersytecie Madryckim już w roku akademickim 1946/1947. Koszty utrzymania placówki pokrywałby rząd hiszpański i amerykańska pomoc społeczna. Koszty wstępne w wysokości od 2 do 3 tys. funtów szterlingów powinna uregulować strona polska ${ }^{33}$.

Rozwinięta przez Józefa Potockiego i poparta przez Franciszka Pułaskiego inicjatywa w sprawie utworzenia polskiego ośrodka uniwersyteckiego w Hiszpanii nie została zrealizowana. Niestety nie jest znana, na obecnym etapie badań, przyczyna tego niepomyślnego stanu rzeczy. Natomiast budującym wielce faktem jest to, że w bardzo trudnych warunkach politycznych powojennej Europy znaleźli się patrioci polscy, którzy nie szczędzili wysiłku, aby nie tylko zachować, ale i rozwijać polskość na obczyźnie.

W tym kontekście warto odnotować, że wśród ważnych inicjatyw, pojawiających się w Paryżu we współpracy z Biblioteką Polską w kilka miesięcy po zakończeniu okupacji niemieckiej we Francji było ufundowanie przez Polską YMCA stypendiów dla Polaków podejmujących trud badań naukowych. Stypendia przydzielała Komisja Stypendialna Polskiej YMCA we Francji pod przewodnictwem Franciszka Pułaskiego w składzie: Wacław Grzybowski, Zdzisław Woydat i Marek Korowicz. W dniu 8 grudnia 1944 r. przyznano na okres pół roku stypendia naukowe w wysokości 4 tys. franków miesięcznie. Wśród trzech stypendystów znalazł się m.in. Władysław Pobóg-Malinowski, który zamierzał opracować publikację pt. „Historia Wojska Polskiego we Francji”. Jednej osobie przydzielono zasiłek jednorazowy w wysokości także 4 tys. franków. Na zebraniu Komisji w dniu 18 stycznia 1945 r. pozytywnie rozpatrzono kandydatury 5 stypendystów. Otrzymali oni stypendia w wysokości 2 tys. franków miesięcznie na okres pół roku za przystąpienie do prac z zakresu nauk technicznych i ekonomicznych. Stypendyści zobowiązani zostali do przedstawienia Komisji stanu zaawansowania podjętych prac po upływie trzech miesięcy. Udzielone wsparcie finansowe miało nie tylko duże znaczenie materialne, ale posiadało także pewien wymiar moralny. Świadczyło o krzepnięciu polskiej diaspory w Paryżu w trudnych, powojenny latach ${ }^{34}$.

Reasumując, należy stwierdzić, Biblioteka Polska w Paryżu pod kierownictwem Franciszka Pułaskiego wykazywała w kilka miesięcy po zakończeniu okupacji niemiec-

\footnotetext{
${ }^{33}$ Ibidem.

34 Ibidem, akc. 6484, Pismo Z. Woydata z 27 czerwca 1945 r. do F. Pułaskiego; ibidem, Komisja Stypendialna polskiej YMCA we Francji.
} 
kiej w tym mieście szereg interesujących inicjatyw w zakresie upowszechniania wiedzy o Polsce. Wszystkie one były zarazem świadectwem prężności działania polskiej instytucji na wyspie św. Ludwika przy Quai d'Orléans 6. Stanowiły dowód, że ta zasłużona placówka gotowa jest dobrze wypełniać patriotyczny obowiązek wobec ojczyzny. Krótka, lecz bardzo znacząca działalność Wyższego Studium Polskiego oraz zasygnalizowane inne formy aktywności Biblioteki są tego najlepszym przykładem. Przyszłość pokazała, że stanowisko to było słuszne i przynosiło zawsze dobre rezultaty.

\section{Bibliografia}

\section{Źródła archiwalne}

Archiwum Instytutu Polskiego i Muzeum im. gen. Władysława Sikorskiego w Londynie, zespół: Ministerstwo Wyznań Religijnych i Oświecenia Publicznego, sygn. A. 19.II/14.

Towarzystw Historyczno-Literackie i Biblioteka Polska w Paryżu, zespół: Archiwum Towarzystwa Historyczno-Literackiego i Biblioteki Polskiej w Paryżu, akcesja 6484.

\section{Opracowania}

Chmielewski W., Przygotowanie kadr oświatowych na uchodźstwie. Seria: Monografie z Dziejów Oświaty, t. XVIII, Polska Akademia Nauk, Warszawa 2013.

Institut Catholique de Paris Centre d'Etudes Slawes Section Polonaise. Programme des Cours Libres année 1945-1946.

Pułaski F., Biblioteka Polska w Paryżu w latach 1893-1948. Odbito na prawach rękopisu w 350 egzemplarzach, Paryż 1948. 